\title{
THE EFFECT OF GOOD CORPORATE GOVERNANCE ON PRODUCTION EFFECTIVENESS
}

\author{
Nita Kanya \\ Universitas Langlangbuana, Indonesia \\ nitakanyacahyono2@gmail.com
}

\begin{abstract}
PT. PLASTIKATAMA is an industrial technology company that runs its business in the production of air pollution control equipment, anti-corrosion equipment, electro-coating systems, chemical tanks, and industrial technology goods made from fiberglass, plastic, and metal as basic materials. Constraints that are being experienced by PT. PLASTIKATAMA, namely the production process is still ineffective, this can be seen from the lack of achievement of targets such as there are still obstacles in the timeliness of producing products, the inaccurate quality of the products produced. The purpose of the author in conducting research is: to know the implementation of Good Corporate Governance at PT. PLASTIKATAMA, to determine the effectiveness of production at PT. PLASTIKATAMA, knowing the influence of Good Corporate Governance on the production process on the effectiveness of the production of PT. PLASTIKATAMA. The results of this study can be used as input and information about the implementation of Good Corporate Governance so that it can be used as a basis for determining the effectiveness of the company's production. For employees at PT. PLASTIKATAMA provides information about the effectiveness of company production and Good Corporate Governance
\end{abstract}

Keyword: Good Corporate Governance; Production Effectiveness

\section{INTRODUCTION}

The state of the economy in Indonesia in recent years has experienced a downturn, this is due to the economic crisis in several countries that have affected Indonesia. As a result of the crisis, many companies experienced difficulties operating because of their near-collapse economic conditions, and many were forced to close their businesses because they could no longer cover the costs incurred to operate. The economic crisis also has an impact on society, because their purchasing power of basic needs has decreased so that their level of welfare has decreased. One of the companies that is difficult to operate, there are still several companies that can withstand the economic crisis, one of which is PT. PLASTIKATAMA. In managing the company, many things become obstacles, one of the most important obstacles to increasing company growth is the lack of public trust in the company which is caused by poor management or management of the company itself. Many companies have ended up going out of business, leaving behind various problems due to improper management and stewardship. Therefore, to support economic growth the company must have effective and efficient management and management. However, this will not work well if it is not supported by good Good Corporate Governance (GCG).

According to research conducted by Soesanto \& Felania (2014), the results show that during the implementation of CGC there was an increase in the five principles of GCG where significant improvements occurred in the principles of transparency and accountability. Furthermore, research from (Purwani, 2010) states that the results of research on the implementation of GCG do not directly affect company performance.

Good Corporate Governance (GCG) according to the Definition of Good Corporate Governance Tunggal (2012), said that Corporate Governance is a system that regulates, manages, and oversees the business control process to increase share value, as well as a form of concern for stakeholders, employees, and the surrounding community. In 
the book Good Corporate Governance Ethical Review in business practices, Hamdani (2016) defines corporate governance as a system that directs and controls a company. The Indonesian Institute for Corporate Governance (IICG) defines GCG as a process and structure that is implemented in running a company, with the main objective of increasing shareholder value in the long term while still paying attention to the interests of others bettors. In addition to fulfilling the interests of shareholders, GCG is intended to ensure sustainability. Apart from that, according to the two experts, the definition of Good Corporate Governance (GCG) was also stated by Kurniawan (2012), said that Good Corporate Governance (GCG) or organizational governance is a set of relationships that occur between management, directors, holders shares, and other stakeholders such as employees, creditors, and public.

Meanwhile, according to Agoes (2011: 101), good corporate governance is a governing system the relationship between the role of the Board of Commissioners, the role of the Board of Directors, the holder shares, and other stakeholders. Good corporate governance well also called a transparent process of determining company goals, achievements, and performance appraisals. According to Mardiasmo (2016), Effectiveness is a measure of the success or failure of achieving the goals of an organization to achieve its goals. The greater the contribution of the resulting output to the achievement of the specified goals or objectives, the more effective the work process of an organizational unit will be.

\section{METHODS}

To prove the correctness of the answers that are still provisional (hypothesis), the researcher collects data on certain objects. The population in this study amounted to 24 people, namely from the quality control section of PT. PLASTIKATAMA. This population was taken from all quality control staff of PT. PLASTIKATAMA, namely to obtain data on the effectiveness of production. Sampling is a statistical practice that deals with the selection of individual observations aimed at understanding the population involved. From the explanation above, the sampling method used is census sampling or saturated sampling because the number used is the same as the number which is the population, which is 24 people from the quality control section of PT PLASTIKATAMA.

Qualitative methods are data processing methods that explain the effects and relationships expressed in sentences. Qualitative analysis is used to see the causative factors.

The quantitative method is a method of processing data in the form of numbers. The quantitative methods in this research are: (1) To see whether there is an effect of operational audit on the production process on the effectiveness of using a calculation tool using the spearman rank correlation counting statistic; (2) To provide an interpretation of the correlation coefficient, the researchers used the following guidelines:

Table 1. Interpretation of the Correlation Coefficient

\begin{tabular}{cc}
\hline Coefficient Interval & Coefficient Interval \\
$0,00-0,199$ & Very low correlation \\
$0,20-0,399$ & Low correlation \\
$0,40-0,599$ & Medium correlation \\
$0,60-0,799$ & Strong correlation \\
$0,80-1,000$ & The correlation is very strong \\
\hline
\end{tabular}

Source: Processed data (2019) 
This analysis is to assess how many variables $X$ (operational audit of the production process) can influence Variable $Y$ (production effectiveness). regarding the meaning of the coefficient of determination, namely:

Hypothesis testing is one way to test a population based on its sample statistics, to be accepted or rejected at a certain level of significance.

The determination of the hypothesis to be tested in this study is related to the presence or absence of a relationship between variable $X$ and variable $Y$, namely the null hypothesis $(\mathrm{H} 0)$ and the alternative hypothesis $(\mathrm{H} 1)$. The hypotheses put forward in this study are research hypotheses and statistical hypotheses: (1) To determine the effect of Good Corporate Governance on Production Effectiveness, a hypothesis is tested using the following assumptions:

$\mathrm{HO}=$ This means that there is no effect of Good Corporate Governance on production effectiveness

$\mathrm{H} 1$ = This means that there is an effect of Good Corporate Governance on production effectiveness

Ho: $\square=0$, meaning that there is no influence of Good Corporate Governance (variable $\mathrm{X}$ ) on production effectiveness (variable $\mathrm{Y}$ ).

$\mathrm{H} 1: \square=0$, which means that there is an effect of Good Corporate Governance (variable $\mathrm{X}$ ) on production effectiveness (variable $\mathrm{Y}$ ).

The level of significance can be determined by testing two parties. To test whether the hypothesis is accepted or rejected, it is done by testing two parties with a significant level $=5 \%$.

\section{RESULT AND DISCUSSION}

Qualitative Analysis of Good Corporate Governance at PT. PLASTIKATAMA

The total results of the questionnaire answers regarding Good Corporate Governance can be seen based on the scores of each Good Corporate Governance indicator in the table below:

Table 2. Total Indicators of Good Corporate Governance

\begin{tabular}{cccc}
\hline No. & Category & Score & Category \\
\hline 1. & Transparency & 324 & Very Good \\
2. & Accountability & 325 & Very Good \\
3. & Responsibility & 327 & Very Good \\
4. & Independency & 323 & Very Good \\
& total & 1299 & Very Good \\
\hline \multicolumn{3}{c}{ Source: Processed data (2019) }
\end{tabular}

Based on the total score of 1299 above, Good Corporate Governance can be said to be very good. The determination of the criteria for the accumulation of the maximum number of answer scores is $5 \times 12 \times 24=1440$ (if the respondent answers by selecting the highest answer score category), and the minimum answer score is $1 \times 12 \times 24=288$ (if the respondent answers by selecting the lowest answer score category).

Qualitative Analysis of Production Effectiveness PT.PLASTIKATAMA

The total results of the answers to the questionnaire regarding production effectiveness can be seen based on the score of each production effectiveness indicator in the table below: 
Table 3. Total Production Effectiveness Indicators

\begin{tabular}{cccc}
\hline No. & Indicator & score & Category \\
\hline 1. & Cost & 317 & Very good \\
2. & Quality & 321 & Very good \\
3. & Dependability & 316 & Very good \\
4. & Flexibility & 326 & Very good \\
& total & $\mathbf{1 2 8 0}$ & Very good \\
\hline
\end{tabular}

Source: Processed data (2019)

Based on the total score of 1280 above, the effectiveness of production can be said to be very good. The determination of the criteria for the accumulation of the maximum number of answer scores is $5 \times 12 \times 24=1440$ (if the respondent answers by choosing the highest answer score category), and the minimum answer score is $1 \times 12 \times 24$ $=288$ (if the respondent answers by selecting the lowest answer score category)

The quantitative method is a method of processing data in the form of numbers. The quantitative methods in this research are: In this discussion, the researcher will discuss the results of the research and test the hypothesis calculated based on the Spearman Rank Correlation. Testing steps: Calculating the ranking of good corporate governance and production effectiveness, by looking at the score of the questionnaire calculation, you can see the ranking of the calculations in the table below, namely:

Table 4. Table Spearman Rank Correlation Calculation Helper

\begin{tabular}{crrrrrrr}
\hline No & $\mathbf{X}$ & \multicolumn{1}{c}{$\mathbf{Y}$} & $\mathbf{R}(\mathbf{X i})$ & $\mathbf{R}(\mathbf{Y i})$ & $\mathbf{R}^{\mathbf{2}}(\mathbf{X i})$ & $\mathbf{R}^{\mathbf{2}}(\mathbf{Y i})$ & $\mathbf{R}(\mathbf{X i}) \mathbf{R}(\mathbf{Y} \mathbf{i})$ \\
\hline $\mathbf{1}$ & 58 & 58 & 20.5 & 19.5 & 420.25 & 380.25 & 399.75 \\
$\mathbf{2}$ & 54 & 54 & 9.5 & 12 & 90.25 & 144 & 114 \\
$\mathbf{3}$ & 56 & 55 & 16 & 14.5 & 256 & 210.25 & 232 \\
$\mathbf{4}$ & 55 & 58 & 12.5 & 19.5 & 156.25 & 380.25 & 243.75 \\
$\mathbf{5}$ & 57 & 59 & 18.5 & 23 & 342.25 & 529 & 425.5 \\
$\mathbf{6}$ & 59 & 59 & 22.5 & 23 & 506.25 & 529 & 517.5 \\
$\mathbf{7}$ & 56 & 58 & 16 & 19.5 & 256 & 380.25 & 312 \\
$\mathbf{8}$ & 56 & 59 & 16 & 23 & 256 & 529 & 368 \\
$\mathbf{9}$ & 55 & 56 & 12.5 & 16 & 156.25 & 256 & 200 \\
$\mathbf{1 0}$ & 60 & 58 & 24 & 19.5 & 576 & 380.25 & 468 \\
$\mathbf{1 1}$ & 58 & 57 & 20.5 & 17 & 420.25 & 289 & 348.5 \\
$\mathbf{1 2}$ & 59 & 53 & 22.5 & 10 & 506.25 & 100 & 225 \\
$\mathbf{1 3}$ & 57 & 55 & 18.5 & 14.5 & 342.25 & 210.25 & 268.25 \\
$\mathbf{1 4}$ & 55 & 54 & 12.5 & 12 & 156.25 & 144 & 150 \\
$\mathbf{1 5}$ & 55 & 54 & 12.5 & 12 & 156.25 & 144 & 150 \\
$\mathbf{1 6}$ & 53 & 50 & 8 & 9 & 64 & 81 & 72 \\
$\mathbf{1 7}$ & 54 & 48 & 9.5 & 4.5 & 90.25 & 20.25 & 42.75 \\
$\mathbf{1 8}$ & 51 & 48 & 6.5 & 4.5 & 42.25 & 20.25 & 29.25 \\
$\mathbf{1 9}$ & 51 & 49 & 6.5 & 7 & 42.25 & 49 & 45.5 \\
$\mathbf{2 0}$ & 49 & 47 & 4.5 & 2.5 & 20.25 & 6.25 & 11.25 \\
$\mathbf{2 1}$ & 49 & 49 & 4.5 & 7 & 20.25 & 49 & 31.5 \\
$\mathbf{2 2}$ & 48 & 49 & 2.5 & 7 & 6.25 & 49 & 17.5 \\
$\mathbf{2 3}$ & 46 & 46 & 1 & 1 & 1 & 1 & 1 \\
$\mathbf{2 4}$ & 48 & 47 & 2.5 & 2.5 & 6.25 & 6.25 & 6.25 \\
total & 1299 & 1280 & 300 & 300 & 4889.5 & 4887.5 & 4679.25 \\
\hline & & Source: Processed data $(2019)$ & & &
\end{tabular}


The calculation of the statistical value in this study uses the Rank Spearman correlation analysis, while the formula for the Spearman Rank correlation for twin data is as follows:

$$
r=\frac{\sum R(X i) R(Y i)-n\left(\frac{n+1}{2}\right)^{2}}{\sqrt{\left[\sum_{i=1}^{n} R^{2}\left(X_{i}\right)-n\left(\frac{n+1}{2}\right)^{2}\right]\left[\sum R^{2}\left(Y_{i}\right)-n\left(\frac{n+1}{2}\right)^{2}\right]}}
$$

Information :

rs = Spearman's rank correlation coefficient

$\mathrm{n}=$ Number of samples

$X=$ Good Corporate Governance

$Y=$ Production Effectiveness

$\mathrm{R}(\mathrm{Xi})=$ Rank on $\mathrm{X}$ for the ith data

$R(Y i)=$ Rank on $Y$ for the ith data

$$
\begin{gathered}
r_{s}=\frac{4679,5-24\left(\frac{24+1}{2}\right)^{2}}{\sqrt{\left[\left[4889,5-24\left(\frac{24+1}{2}\right)^{2}\right]\left[4887-24\left(\frac{24+1}{2}\right)^{2}\right]\right]}} \\
r_{s}=\frac{4674,75-3750}{\sqrt{[4889,5-3750][4887-3750]}} \\
r_{s}=\frac{929,25}{\sqrt{(1139,5)(1137,5)}} \\
r_{s}=\frac{929,25}{\sqrt{1296181,25}} \\
r_{s}=0,816205848=0,816
\end{gathered}
$$

\begin{tabular}{|c|c|c|c|c|}
\hline & & & $\mathbf{x}$ & $\mathbf{y}$ \\
\hline \multirow[t]{6}{*}{$\begin{array}{l}\text { Spearman's } \\
\text { rho }\end{array}$} & $\mathrm{x}$ & $\begin{array}{l}\text { Correlation } \\
\text { Coefficient }\end{array}$ & 1,000 &, $816\left({ }^{* *}\right)$ \\
\hline & & Sig. (2-tailed) & . & ,000 \\
\hline & & $\mathrm{N}$ & 24 & 24 \\
\hline & $y$ & Correlation &, $816\left({ }^{\star *}\right)$ & 1,000 \\
\hline & & Sig. (2-tailed) & ,000 & \\
\hline & & $\mathrm{N}$ & 24 & 24 \\
\hline
\end{tabular}

After calculating manually, it can be seen that the magnitude of the correlation or relationship between good corporate governance and production effectiveness is 0.816 . The following are the results of the rs obtained using SPSS 14.0 for Windows.

\section{Table 5. Hypothesis Test Results}

\section{Correlations}


From the results above, both manual and manual hypothesis testing using SPSS 14.0 for Windows can be seen that $r s=0.816$. This shows that there is a very strong correlation between good corporate governance and production effectiveness, meaning that if good corporate governance activities have been implemented properly, the achievement of the level of effectiveness will be good too. The main objective of good corporate governance is to achieve the level of effectiveness of the activities of a function within the company, in this case, production.

In knowing the percentage of the influence of good corporate governance on production effectiveness, the researcher uses the coefficient of determination (Kd) analysis, with the following formula:

Information :

$$
K d=r_{s}^{2} * 100 \%
$$

$\mathrm{Kd}=$ coefficient of determination

rs = Spearman's rank correlation coefficient

$\mathrm{Kd}=0$ means that the effect of variable $X$ on $Y$ is weak

$\mathrm{Kd}=100 \% / 1$ means that the influence of variable $X$ on $Y$ is strong

$$
\begin{aligned}
& K d=r_{s}^{2} * 100 \% \\
& K d=(0,816)^{2} * 100 \% \\
& K d=0,665856 * 100 \% \\
& K d=66,58 \%
\end{aligned}
$$

From the results of the calculation of the coefficient of determination, it can be seen that the magnitude of the influence of good corporate governance on production effectiveness is $66.58 \%$, so the implementation of good corporate governance which is carried out very well can have an influence on the increase in the achievement of production effectiveness, which is $66.58 \%$. While $33.42 \%$ is another factor that also influences the effectiveness of production. Other factors, such as the committee held in carrying out their duties, cooperation, and coordination between departments in the company and the condition or condition of the company.

Ho: $\square=0$, meaning that there is no effect of good corporate governance (variable $X$ ) on production effectiveness (variable $Y$ ).

$\mathrm{H} 1: \square=0$, meaning that there is an effect of good corporate governance (variable $X$ ) on production effectiveness (variable $Y$ ).

The formula used to test the statistical hypothesis in research on the effect of good corporate governance on production effectiveness is the test as follows:

$$
=\frac{r_{s} \sqrt{n-2}}{\sqrt{1-r_{s}^{2}}}
$$

By using this formula, it can be seen whether the research hypothesis that good corporate governance affects production effectiveness can be proven.

The results of the calculation are from the t-test as follows: 


$$
\begin{aligned}
= & \frac{0,816 \sqrt{24-2}}{\sqrt{1-(0,816)^{2}}} \\
= & \frac{3,82737926}{0,5780519} \\
t_{\text {count }}= & 6,621168895 \approx 6,621
\end{aligned}
$$

Based on the above calculations, it can be seen that the amount is 6.621 using a significance level of $5 \%$ and the number of respondents is 24 , it can be seen that the magnitude of the t table is 2.064. Based on the comparison between $t_{\text {count }}$ and $t_{\text {table, }}$, it can be seen that $t_{\text {count }}$ is greater than $t_{\text {table, }}$, which is 2.064 . This shows that $\mathrm{Ho}$ is rejected and $\mathrm{H} 1$ is accepted by referring to the following criteria: If $t>$ than $t$, then $\mathrm{H}$ is rejected, $\mathrm{H}$ is accepted If $t<$ of $t$, then $H$ is accepted, $H$ is rejected This means that good corporate governance has a significant effect on production effectiveness.

Every company needs to carry out good corporate governance to ensure whether its activities are carried out following the right efforts to achieve its effectiveness or not. There is a very strong correlation between good corporate governance and production effectiveness, meaning that if good corporate governance activities have been implemented properly, the achievement of the level of effectiveness will also be good following one of the objectives of good corporate governance, namely achieving the level of effectiveness indicated by the very high correlation results. strong which is equal to 0.816. Therefore, it can be seen that the effect of good corporate governance on production effectiveness after an analysis is carried out, namely. While $33.42 \%$ is another factor that also influences the effectiveness of production. Other factors such as commitment in carrying out their duties, cooperation, and coordination between parts in the company and the condition or condition of the company. Good corporate governance also has a significant influence on the effectiveness of production, as indicated by the amount of $t$ count is greater than $t$ table, namely $6.621>2.064$. This proves the research hypothesis that good corporate governance has a significant effect on production effectiveness.

\section{CONCLUSION}

Based on the results of the research and discussion that has been put forward by the researcher in the previous chapter, the researcher can draw the following conclusions: The implementation of Good Corporate Governance at PT PLASTIKATAMA has been carried out very well This shows that the stages of Good Corporate Governance at PT PLASTIKATAMA include Transparency (Openness), Accountability (Accountability), Responsibility (Responsibility), Independency (Independence) have been implemented well once. The production effectiveness at PT.PLASTIKATAMA can be said to be very good. Effectiveness is achieved marked by the company's production targets have been achieved, namely the accuracy of cost efficiency incurred, the accuracy of the number of quality products produced, achieved dependability and flexibility. From the calculation of the coefficient of determination, it is obtained $66.58 \%$. This shows that the influence of Good Corporate Governance on the effectiveness of production is $66.58 \%$. Meanwhile, $33.42 \%$ is another factor that influences Good Corporate Governance on production effectiveness. Other factors such as commitment to carry out their duties, cooperation, and coordination between parts in the company and the condition or condition of the company. 


\section{REFERENCES}

Agoes, Sukrisno. (2011). Etika Bisnis dan Profesi. Jakarta: Salemba Empat

Hamdani. 2016. Good Corporate Governance: Tinjauan Etika dalam Praktik Bisnis. Jakarta: Mitra Wacana Media.

Kurniawan, Ardeno. 2012. Audit Internal Nilai Tambah Bagi Organisai. Edisi pertama. Yogyakarta : BPFE

Mardiasmo. (2016). Efisiensi dan Efektifitas. Jakarta: Andy.

Purwani, Tri. (2010). Pengaruh Good Corporate Governance Terhadap Kinerja Perusahaan. Majalah IImiah INFORMATiKA.

Soesanto, Callysta \& Felania, Yie Ke. (2014). Analisis Efektivitas Implementasi Goog Corporate Gorvernance. Jurnal IImiah Mahasiswa Surabaya.

Tunggal, A. W. (2012). intisari internal audit. rineka cipta. 